\title{
MCF2 wt Allele
}

National Cancer Institute

\section{Source}

National Cancer Institute. MCF2 wt Allele. NCI Thesaurus. Code C52879.

Human MCF2 wt allele is located within Xq27 and is approximately $70 \mathrm{~kb}$ in length. This allele, which encodes proto-oncogene DBL protein, is involved in modulating the activity of proteins in the Rho family of GT Pases. 